\title{
The Folk High School: A Contemporary Educational Pathway for Swedish Parliamentarians?
}

Henrik Nordvall and Fridolfsson Fridolfsson

The self-archived postprint version of this journal article is available at Linköping University Institutional Repository (DiVA):

http:// urn.kb.se/ resolve?urn=urn:nbn:se:liu:diva-140998

N.B.: When citing this work, cite the original publication.

This is an electronic version of an article published in:

Nordvall, H., Fridolfsson, F., (2019), The folk high school - a contemporary educational pathway for Swedish parlamentarians?, Scandinavian J ournal of Educational Research, 63(3), 347-362.

https:/ / doi.org/ 10.1080/00313831.2017.1375006.

Original publication available at:

https:/ / doi.org/ 10.1080/ 00313831.2017.1375006.

Copyright: Taylor \& Francis (Routledge) (SSH Titles) and the Authors, Open Access published.

http:// www.routledge.com/ 
Nordvall, H., \& Fridolfsson, F. (2019). The folk high school - a contemporary educational pathway for Swedish parlamentarians? Scandinavian Journal of Educational Research, 63(3), 347-362. https://doi.org/10.1080/00313831.2017.1375006.

\title{
The folk high school - a contemporary educational pathway for Swedish parliamentarians?
}

Henrik Nordvall (corresponding author), Associate Professor, Department of Behavioural Sciences and Learning, Linköping University. E-mail: henrik.nordvall@liu.se

Charlotte Fridolfsson, Associate Professor, Department of Management and Engineering, Linköping University. Email: charlotte.fridolfsson@liu.se

\begin{abstract}
The aim of this study is to explore the contemporary role of the folk high school as an educational pathway for Swedish MPs. Statistics from the folk high school register at Statistics Sweden are analysed. In summary, there are still quite a large number of former folk high school participants in the Swedish parliament $(27 \%, 2014)$. The MPs' folk high school participation mainly took the form of short courses. Over time, the folk high schools have increasingly come to be used by members of parties on the left of the political spectrum. The folk high schools are commonly used as meeting places during the MPs' political career, and thus not only as an educational pathway to power, as emphasised in earlier research.
\end{abstract}

Key words: Folk high schools; Swedish parliamentarians; popular education; organisational capital.

It is an internationally renowned pattern that elected parliamentarians as a group generally have a higher education than the average population (Bourdieu, 1996; Best and Cotta, 2000; Gaxie \& Godmer, 2007; Norris \& Lovenduski, 1995). In some countries, there is also a clear link between political power and some elite institutions of education that have become important passages for a successful political career. In France, for example, special elite institutions in the education system, such as Ecole Nationale d'Adminstration, have become compulsory passages for politicians seeking prominent roles in parliament or the cabinet (Bourdieu, 1996; Gaxie \& Godmer, 2007). In the UK, a similar pattern has been highlighted, where the path to political power often passes through Oxford or Cambridge, which has led to the coining of a specific concept in social science: the "Oxbridge phenomenon" (Norris \& Lovenduski, 1995; Ye \& Nylander, 2015).

This so-called Oxbridge phenomenon, however, does not seem to exist in Scandinavia (Broady, 1990; Gaxie \& Godmer, 2007). Although there is an overrepresentation of people with higher education among politicians, especially in higher positions, in Scandinavia, political leaders in Sweden, Denmark and Norway have relatively modest educational credentials compared to other comparable liberal democracies (Gaxie \& Godmer, 2007; Göransson, 2007; Hartmann, 2010; Lie Andersen, 2014;). In Sweden, which is the empirical focus of this article, this has been seen as a result of how social movements and popular education historically have shaped Swedish 
society (Broady, 1990; Rothstein, 1992).

Donald Broady (1990) has discussed Bourdieu's studies of the French political elite and their relevance to the Swedish political field, and stresses that the results are not transferable in the sense that a similar cultural capital (university education from specific prestigious academic intuitions) would be of the same importance in Sweden. Instead, Broady suggests other types of assets that could have a similar function in Swedish society, where the Swedish political elite tends to have a broader social base than is usual in most other countries. Among other things, Broady highlights the importance of an "organisational capital", i.e. the type of assets acquired through associations and key educational institutions within social movements (Broady, 1990). In Sweden, some social movement-run folk high schools, such as the labour movement's Brunnsvik folk high school, have been identified in previous research as nurseries for political and trade union leaders in Sweden (Berggren, 1988; Erickson, 1966; Helldén, 1968). During the 1930s and 1940s, folk high school education became close to a prerequisite for a successful political career in the Swedish labour movement (Pauli, 2012, p. 76). The movement's folk high schools' courses were designed both to compensate for limited formal education and to provide education specifically required for functions within the movement (Pauli, 2012, p. 40).

Herman Erickson (1966) and Arne Helldén (1968) showed that a significant number of the members of the Swedish Riksdag (the parliament) among most political parties during the 1960 s had a background as folk high school students. A later study also showed a continued significant proportion of the Members of Parliament (MPs) having a folk high school background (Andersson \& Lönnström, 1982). No current picture of Swedish parliamentarians' folk high school participation existed prior to the study presented here. Folk high school studies are usually not recognised as a special category when MPs' educational background is screened (see Holmberg \& Esaiasson, 1988; Statistics Sweden, 2016). However, the term "the parliament folk high school group" used by Helldén (1968) has been revived in various contexts, including as a possible explanation for popular education's strong and broad political support in Sweden, and as a possible factor behind the large-scale state grant-funded popular education sector (cf. Bogärde, 1974; Maliszewski, 2008; Runesdotter, 2010).

Sweden, as most of the Nordic countries, has a state-funded sector for non-formal and popular education, providing support to folk high schools. The folk high schools are often closely linked to civil society and provide education for youth and adult participants, generally without providing formal merits. State funding is motivated mainly by the folk high schools' assumed potential to strengthen democracy and provide alternative educational opportunities for a broad spectrum of the population (Johansson \& Bergstedt, 2015; Rubenson, 2013). Although folk high schools may be found across Scandinavia and Finland, a difference between the countries is in the role of the schools. While the link to political movements is strong in Sweden, the Norwegian folk high schools are dominated by Christian organisations (Lövgren, 2015). In Denmark, popular movements played a less crucial role in the development of the folk high school: instead, they have largely been founded either by individuals or by local community initiatives (Canfield, 1965). However, despite national differences, a substantial proportion of parliamentarians in Scandinavia have a folk high school background, at least until the 1960s (Helldén, 1968, p. 63-64). ${ }^{1}$

\footnotetext{
${ }^{1}$ Helldén (1968, p. 63-43) located 37 former folk high school students (out of 179 MPs in total) in the Danish parliament of 1967 and 26 (out of 150) in the Norwegian parliament the same year. To our knowledge, there are no up-to-date figures on the current situation.
} 
This study is part of a larger research project ${ }^{2}$ examining how formal education, popular education and informal learning processes affect selection and recruitment of political elites (primarily parliamentarians and members of the cabinet) in Sweden. In light of the folk high schools' historical position in relation to the schooling of political leaders, and the specific attention given to the folk high schools' relation to parliamentarians in the literature mentioned above, we find it relevant to address this as a specific topic. In this article, we examine whether and how folk high schools are still used as educational pathways for parliamentarians in contemporary Sweden. Furthermore, the intention is to provide insights on a subject of significance in order to comprehend the contemporary relevance of the organisational capital described by Broady; if it still could be assumed to be crucial for the reproduction of the kinds of elite political positions that MPs hold. ${ }^{3}$ In other words, the motivation behind this research is to investigate whether, how and to what extent folk high schools, both in general and in terms of specific institutions, could still be considered an arena for reproduction and fostering of political leaders in Sweden. Questions asked are: is it still possible to locate a "parliament folk high school group" in the Riksdag? If so, what characterises the folk high school's current role as an educational pathway for Swedish MPs? In particular, we focus on aspects of "the parliament folk high school group" highlighted in previous research, patterns related to specific folk high schools, and how folk high school participation seems to relate to MPs' overall educational background.

The data is mainly based on statistics from the folk high school register at Statistics Sweden, and this is the first time that the register has been used to investigate MPs' educational pathways. This study's target group is MPs elected in 2010 and 2014. Besides wanting to obtain as current a picture as possible, these two MP cohorts were also chosen due to their folk high school participation being best covered by this relatively new registry.

\section{The parliament folk high school group}

Previous research on Swedish politicians' educational background shows the importance of popular education and its institutions. Folk high schools have played a central role as educational institutions for political leaders. After their introduction in Sweden in the latter half of the 1800 s, folk high schools became an important educational pathway for farmer representatives in political bodies. Folk high schools and study circles were also central to the training of trade union and political leaders within the labour movement in the early 1900s (Arvidson, 1985; Larsson, 2013). Helldén's study of the "folk high school group" in the Swedish Riksdag-based on biographies, student rolls from some schools, questionnaires and interviews - shows that of all the MPs in 1967 (then 382 representatives in total), 74 members had passed a long folk high school course, of which 22 members attended the labour movement folk high school Brunnsvik. Folk high school students were found in all parties, except in the Communist Left Party. The Social Democrats, with 42 former folk high school students, and the agrarian Centre Party with 22, were clearly overrepresented (Helldén, 1968, pp. 73-74). At the time, both parties represented broad popular movements: the labour movement and the farmers' movement, respectively. In Helldén's interviews with MPs about how they were influenced by their folk high school experiences, it was revealed that the MPs considered their participation in the longer courses as an important experience in different ways. The kind of impact that emerged from the studies seemed to concern cultural, intellectual and personal development, rather than the triggering of political commitment (since most already had a political

\footnotetext{
${ }^{2}$ Funded by the Swedish Research Council's Committee for Educational Sciences.

${ }^{3}$ When we refer to parliamentarians as part of the political elite, we do so due to their close proximity to (national) political power and policymaking, which is a loose but widespread definition in the literature (ch. Lilleker, 2003). Thus, we do not refer to the narrower definition used, for example, in previous studies of power and democracy in Sweden (Göransson, 2007; SOU, 1990:44).
} 
commitment prior to their studies). A certain variation among the MPs could be observed depending on their class background. Members who during childhood had limited or no contact with academic studies or arts and literature highlighted the value of being introduced to these at the folk high school. Members who were already familiar with such areas from their upbringing instead emphasised the benefits of meeting people from different backgrounds and with different values than themselves (Helldén, 1968).

American political scientist Herman Erickson's (1966) study of political leaders in Sweden was carried out prior to Helldén's, and focused on MPs from 1961 to 1962. The study addressed both the limited proportion of MPs who had formal education above elementary school level (34\%) and the prevalence of popular education, including folk high school studies, among the others. Folk high schools, especially Brunnsvik, were pointed out as being a central educational pathway for political leaders in Sweden. Erickson (1966, p. 139) interpreted the widespread incidence of popular education among political leaders as a possible consequence of its informal teaching mode, requiring a high degree of initiative on the part of the participant, and thus fostering what is usually seen as an important leadership skill. Erickson also pointed out the folk high schools' formative significance on the basis that participants in the residential courses live together and specifically focus on the studies, which is not the case, for example, in study circles and correspondence courses (Erickson, 1966). Singling out Brunnsvik as a kind of cadre school for MPs in the labour movement was also confirmed in Erickson's research. Historian Henrik Berggren's study of Brunnsvik should also be mentioned in this context; it showed that a number of students who completed a winter course at Brunnsvik before 1920 made careers as MPs or journalists and were given various appointments within the labour movement (Berggren, 1988).

A survey of MPs' participation in popular education (with a response rate of 89.1\%), completed in 1977 and 1978, indicated a high proportion of folk high school participants (Andersson \& Lönnström, 1982): 23\% of MPs stated that they had taken part in (long) folk high school courses (Andersson \& Lönnström, 1982, p. 95). The proportion of members who attended folk high schools was largest among the Centre Party members (33.3\%), followed by the Social Democrats (27.7\%). The Left Party still had the lowest percentage of participants (6.7\%). An unpublished study with the same survey design was carried out in 1989/1990 (with a response rate of 81.7\%), and this indicated that the overall proportion of MPs with a folk high school background declined in the 1980 s to $14.7 \%$ (Sundqvist, 1990). The proportion of folk high school participants was highest among the Social Democrats (20.6\%) and the Centre Party (18.4\%). The Left Party, which previously had the lowest proportion, now increased to $15.4 \%$. The Green Party, which was new to the parliament at the time, completely lacked former folk high school students (Sundqvist, 1990).

The presence of MPs with a folk high school background has also played a role in political decisions concerning popular education, according to Bo Bogärde's dissertation in political science on the Swedish folk high school teachers' association and its political influence (Bogärde, 1974). Bogärde points to the importance of a "folk high school party" in parliament, composed of members from different political parties with a background in the folk high school (Bogärde, 1974, p. 66). Such folk high school-affiliated groups in parliament, with a strong commitment to promoting the folk high school, can be traced all the way back to the 1870 s. They were also often listened to in cabinet circles, which Bogärde explains was due to the "politically neutral status" of issues related to the folk high schools, as those issues transcend party lines (p. 60). The growing number of MPs in parliament with a folk high school background up until 1960 meant that the folk high school sector had a strong and easily accessible way into the country's highest political body. However, even before that, Bogärde notes (1966, p. 59) that a "historically emerged folk high school resonance" was the reason for the support of folk high 
schools by the parliament.

The issue of a historic link between the folk high school and MPs was raised in various adult education research contexts after these studies were conducted (Berntsson, 2003; Maliszewski, 2008; Runesdotter, 2010). The extent to which this link prevails, however, has thus far been scarcely researched. Given the major educational reforms that have taken place since the 1960s, such as the introduction of secondary schools and expansion of the college and university system, there is reason to believe that folk high schools have had less significance as preparatory training institutions of the political elite. There are also reports that the proportion of former folk high school participants in parliament decreased during the 1980s (Sundqvist, 1990). Meanwhile, political support for folk high schools remained strong in parliament, at least in terms of the level of state subsidies to popular education (which includes the funding of folk high schools). Regardless of cabinet majorities, financial support has remained, with a slight increase, at about the same level for the last 20 years (Fejes \& Nordvall, 2014). We also know that academic education is far from a prerequisite for a successful political career in Sweden, where, for instance, less than $50 \%$ of Social Democratic MPs in 2010 had a post-secondary education (Nordvall \& Malmström, 2015).

\section{Method and material}

This study is based on register data on Swedish MPs from Statistics Sweden. The database includes information about candidates elected to the national parliament from 1991 to 2014. The main focus of this study is elected MPs from 2010 and/or 2014, with a total number of 486 individuals. The main reason we decided to focus on this current cohort is that we are primarily interested in the contemporary account of folk high school participation in today's parliament. Another reason has to do with the limitations in the Statistics Sweden folk high school register, which contains more reliable data covering the latter cohorts than previous cohorts. We want to emphasise, however, that there is a discrepancy between the registered course attendance and actual experience of folk high school education - participation in folk high school courses is probably significantly beyond what the records show. Comprehensive information for participation in courses at folk high schools has been collected since 2008. Data has been available for registrations of general and special courses since 1998, which usually involves courses that are one semester or longer. The general course participants gain eligibility for college the same way as through public adult education offered by municipalities. Special courses aim not to facilitate general qualification but have an array of orientations, such as music, art, language, journalism or particular themes determined by the folk high schools themselves. From 2008 onwards, it was mandatory to also report individual data on participation in short courses (1-14 days) to Statistics Sweden. Short courses can, for example, be weekend courses of various kinds, though even here there is great variation in orientation. The content of the short course is shaped either by the folk high school itself or in collaboration with an external organisation running its course at the folk high school. The short courses could be either oriented towards the general public - as is often the case with summer courses in such subjects as art and creative writing - or directed towards the members of a specific organisation, such as trade union courses.

Notwithstanding the school register's limitations, it still provides a reasonable basis to gain a picture of whether it is still appropriate to speak of a folk high school group in parliament, measuring the proportion of MPs with experience of participation. The registry also provides insights into the character of the actual folk high school courses taken and links to specific schools that might be significant pathways for the Swedish political elite.

In our study of what we call the parliament folk high school group, we included all MPs listed in the folk high 
school records, including those participating in short courses only. This particular form of folk high school participation has not been systematically studied in previous research, since data was difficult to collect before the centrally coordinated register. The short courses have been offered in volume since at least the 1960s (Maliszewski, 2008, p. 84). We considered it reasonable to allow the investigation to cover all types of folk high school courses, as we have had the opportunity to explore them through the register and thus reveal different forms of folk high school participation within the political elite.

Simple descriptive statistical analysis was conducted on the data from Statistic Sweden using SPSS software. When analysing data, we have focused on aspects of the "parliament folk high school group" highlighted in previous research, such as its political composition, patterns related to specific folk high schools, and the ways in which folk high school participation seems to relate to the MPs' overall educational background (Helldén, 1968; Andersson \& Lönnström, 1982). To contextualise the results we have also, when deemed relevant, used available information about folk high schools from the Swedish National Council of Adult Education (Folkbildningsrådet) and the folk high schools' own websites.

\section{A folk high school group still exists in parliament}

The folk high school register shows quite clearly that it is still possible to identify a significant number of MPs who have been participants in folk high school courses. Of the 349 elected MPs in 2014, 95 persons, or 27\%, had participated in some type of folk high school course. Table 1 shows that this participation is characterised by distinct patterns, both in terms of which party group's participation is common and the types of courses undertaken.

Table 1. Participation in folk high school courses among members of the 2014 Swedish Riksdag: Percentage by party and course type.

\begin{tabular}{|c|c|c|c|c|c|}
\hline Party name & $\begin{array}{c}\text { Number of MPs } \\
\text { in Riksdag }\end{array}$ & $\begin{array}{c}\text { General course } \\
\text { participants } \\
\%(N)\end{array}$ & $\begin{array}{c}\text { Special course } \\
\text { participants } \\
\%(N)\end{array}$ & $\begin{array}{c}\text { Short course } \\
\text { participants } \\
\%(N)\end{array}$ & $\begin{array}{c}\text { Participated in any } \\
\text { course } \\
\%(N)\end{array}$ \\
\hline Centre Party & 22 & $4.5(1)$ & $4.5(1)$ & $13.6(3)$ & $22.7(5)$ \\
\hline Christian Democrats & 16 & - & $6.3(1)$ & $6.3(1)$ & $12.5(2)$ \\
\hline Green Party & 25 & - & - & $48.0(12)$ & $48.0(12)$ \\
\hline Left Party & 21 & $9.5(2)$ & $9.5(2)$ & $47.6(10)$ & $57.1(12)$ \\
\hline Liberals & 19 & - & $5.3(1)$ & $5.3(1)$ & $10.5(2)$ \\
\hline $\begin{array}{r}\text { Moderate Party } \\
\text { (conservative) }\end{array}$ & 84 & - & $1.2(1)$ & $2.4(2)$ & $3.6(3)$ \\
\hline Social Democrats & 113 & $2.7(3)$ & $10.6(12)$ & $47.8(54)$ & $49.6(56)$ \\
\hline $\begin{array}{l}\text { Sweden Democrats } \\
\text { (nationalist) }\end{array}$ & 49 & $2.0(1)$ & - & $4.1(2)$ & $6.1(3)$ \\
\hline All & 349 & $2.0(7)$ & $5.2(18)$ & $24.3(85)$ & $27.2(95)$ \\
\hline
\end{tabular}

The Social Democrats, Green Party and Left Party have the largest proportion of MPs who participated in folk high school. The Centre Party, which stood out in the previous folk high school group, are in fourth place among those elected in 2014. If we only take into account longer courses (general and specific), which would create greater comparability with previous studies, it is in the Social Democrats, the Left Party and the Centre Party that we find the largest numbers. The Centre Party and the Social Democrats have, ever since studies of the folk high school group began, distinguished themselves as having a high number folk high school students among their MPs (Erickson, 1966; Helldén, 1966; Andersson and Lönnström, 1982) and the relative increase in participation of the Left Party that was noted in 1989/1990 (Sundqvist, 1990) still remains. 
The proportion of men (49.5\%) and women (50.5\%) in the folk high school group is even. In relation to there being fewer women (43.6\%) than men (56.4\%) in the Swedish parliament since the 2014 election, women are slightly overrepresented. However, this should be understood in relation to the presence of parties, such as the Liberals and the Sweden Democrats, that have a high proportion of men ( $73.7 \%$ and $77.6 \%$, respectively) among their MPs and relatively few former folk high school participants.

Swedish parliamentary politicians have primarily taken part in short courses with a timespan of between 1 to 14 study days. Short courses seem particularly common among MPs of the Left Party, the Green Party and the Social Democrats, who all have nearly $50 \%$ of their MPs registered as short course participants (compared to the average of $24 \%$ among all MPs). Based on the course titles, most of them are linked to party work. Among the most popular are "Board Education", "Leader 600", "Electoral Education," and "Trade Union and Politics Conference". They are mainly courses on board leadership and courses related to specific political themes.

Furthermore, we see that only $2 \%$ of the MPs have been registered participants of a general course since 1998. Hence, folk high school participation in the contemporary Riksdag is not characterised as an alternative to other formal education pathways, which was more often the case in the former folk high school group in parliament. Commonly, for MPs who went to folk high schools in the mid-1900s, the courses served as further studies after basic elementary school and distance course studies (Helldén, 1968). The changed prevalence is no surprise given the expansion of the educational system and the generally increased education level in the population as a whole. But we see that the folk high school, through its other course types (special and short courses), is still a form of education experienced by individuals elected to parliament.

It is no longer chiefly people who lack academic education that are found among the folk high school participants in parliament. Instead, as shown in Table 2, the new folk high school group consists to a very large extent of MPs with three or more years of higher education (46\%). The difference between the parties in this regard is reflected in the large difference between the groups' educational composition in general.

Table 2. Educational attainment among members of the Swedish Riksdag elected in 2014 who had participated in folk high school courses.

\begin{tabular}{|c|c|c|c|c|c|}
\hline \multirow{2}{*}{ Party } & \multicolumn{4}{|c|}{ Highest level of education } & \multirow[b]{2}{*}{$\begin{array}{l}\text { Total } \\
\%(N)\end{array}$} \\
\hline & $\begin{array}{c}\text { Primary or lower } \\
\text { secondary education } \\
\%(N) \\
\end{array}$ & $\begin{array}{l}\text { Upper secondary } \\
\text { education } \\
\%(N) \\
\end{array}$ & $\begin{array}{c}\text { Post-secondary } \\
\text { education, less than } 3 \\
\text { years } \\
\%(N)\end{array}$ & $\begin{array}{c}\text { Post-secondary } \\
\text { education, more than } 3 \\
\text { years } \\
\%(N)\end{array}$ & \\
\hline Centre Party & - & - & - & $100.0(5)$ & $100.0(5)$ \\
\hline $\begin{array}{l}\text { Christian } \\
\text { Democrats }\end{array}$ & - & - & $50(1)$ & $50(1)$ & $100(2)$ \\
\hline Green Party & - & - & $16.7(2)$ & $83.3(10)$ & $100.0(12)$ \\
\hline Left Party & $8.3(1)$ & $16.7(2)$ & $16.7(2)$ & $58.3(7)$ & $100.0(12)$ \\
\hline Liberals & - & - & $50(1)$ & $50(1)$ & $100.0(2)$ \\
\hline $\begin{array}{l}\text { Moderate } \\
\text { Party }\end{array}$ & - & - & $66.7(2)$ & $33.3(1)$ & $100.0(3)$ \\
\hline $\begin{array}{l}\text { Social } \\
\text { Democrats }\end{array}$ & $12.5(7)$ & $35.7(20)$ & $19.6(11)$ & $32.1(18)$ & $100.0(56)$ \\
\hline $\begin{array}{l}\text { Sweden } \\
\text { Democrats }\end{array}$ & - & $33.3(1)$ & $33.3(1)$ & $33.3(1)$ & $100.0(3)$ \\
\hline All & $8.4(8)$ & $24.2(23)$ & $21.1(20)$ & $46.3(44)$ & $100.0(95)$ \\
\hline
\end{tabular}

While a clear majority (67\%) of the folk high school attendees also have post-secondary education, there are still 
indications that the folk high school, at least to some extent, performs a compensatory function in relation to the formal education system, which was emphasised in relation to the former folk high school group in parliament. If we consider the percentage of folk high school students out of the total number of MPs in each education category, it is highest among those who have only lower secondary education. It was indeed only about 16 individuals in the 2014 Riksdag, but out of these, eight (50\%) have attended folk high school courses. As for the other three education categories, the folk high school participation rate is between $23 \%$ and $28 \%$. However, since an absolute majority of the MPs who lack secondary education are Social Democrats, the strong connection to the folk high school in this group is not merely related to educational level (rather, the party dimension seems decisive).

However, if we consider the variations in folk high school participation between different constituencies, it is clear that it is not only the party differences that stand out as distinctive. There are also clear geographical differences. The lowest proportion of MPs with registered folk high school participation is found in western Skåne county circuit (none of the 11 selected MPs are found in the folk high school register), Malmö municipality (9.1\%, or 1 of 11 members) and the City of Stockholm (9.4\%, or 3 of 32). Thus, in general, few folk high school participants are found in the electoral districts of southern Sweden and the Stockholm area. The highest proportion is found in Norrbotten and Västerbotten counties in the north of Sweden, where 75\% (6 of 8) and 70\% (7 of 10) of the MPs have participated in a folk high school course. From this, one cannot conclude that the geographic differences in folk high school participation are only related to differences between densely populated metropolitan areas versus less densely populated areas, even if it emerges as a significant part of the explanation. In Gothenburg ${ }^{4}$ municipality constituency, for example, a relatively high proportion of folk high school participants are found among the elected MPs (47.1\%, or 8 of 17). Furthermore, the geographical differences do not merely reflect the differences between the various parties' electoral support in respective constituencies, i.e. the figures do not primarily reflect the fact that the bourgeois parties have greater representation in Stockholm than in Västerbotten. The geographical differences are noticeable even if this is taken into consideration, which becomes evident when we look at the Social Democrats, as none of the party's MPs who were elected in Stockholm Municipality (7 members) or Malmö (3) had participated in folk high school courses according to the register. However, all Social Democratic MPs from Västerbotten (5) and Norrbotten (5) have participated in some form of folk high school course.

\section{Still a high concentration of MPs at some folk high schools}

In previous research, some folk high schools were highlighted as particularly prominent when it comes to education of political leaders and members of parliament. The most striking example is Brunnsvik, which was the folk high school in the Helldén study with the most alumni in parliament (Helldén, 1968). In the register, we can see that there is still a clear pattern of folk high schools that stand out in this regard. To increase the possibility of locating patterns linked to individual schools, we have included MPs elected in both 2010 and 2014 below in Table 3, resulting in a slightly larger population $(\mathrm{N}=486)$. Out of the 150 folk high schools that existed in 2014, from which our latest data is derived, our analysis shows that there is a clear concentration to ten schools, attended by more than half of the former folk high school participants in parliament (see Table 3).

\footnotetext{
${ }^{4}$ The second largest city in Sweden.
} 
Table 3. The 10 most common folk high schools for Swedish MPs elected in 2010 and 2014.

\begin{tabular}{|c|c|c|c|c|}
\hline Name of school & Municipality (County) & $\begin{array}{c}\text { Year } \\
\text { founded }\end{array}$ & Movement affiliation & $\begin{array}{c}\text { Number of MPs } \\
\text { attended }\end{array}$ \\
\hline Medlefors folk high school & $\begin{array}{l}\text { Skellefteå } \\
\text { (Västerbotten) }\end{array}$ & 1946 & Labour movement & 23 \\
\hline $\begin{array}{l}\text { The labour movement's folk high } \\
\text { school in Viskadalen }\end{array}$ & $\begin{array}{l}\text { Borås (Västra } \\
\text { Götaland) }\end{array}$ & 1928 & Labour movement & 18 \\
\hline Brunnsviks folk high school & Ludvika (Dalarna) & 1906 & Labour movement & 13 \\
\hline Färnebo folk high school & $\begin{array}{l}\text { Sandviken } \\
\text { (Gävleborg) }\end{array}$ & 1991 & $\begin{array}{l}\text { Peace, solidarity, and } \\
\text { environmental movement }\end{array}$ & 13 \\
\hline Sunderby folk high school & Luleå (Norrbotten) & 1896 & Labour movement & 12 \\
\hline Runö folk high school & $\begin{array}{l}\text { Österàker } \\
\text { (Stockholm) }\end{array}$ & 1953 & Labour movement & 11 \\
\hline Tollare folk high school & Nacka (Stockholm) & 1952 & Temperance movement & 8 \\
\hline Marieborgs folk high school & $\begin{array}{l}\text { Norrköping } \\
\text { (Östergötland) }\end{array}$ & 1934 & Labour movement & 8 \\
\hline $\begin{array}{l}\text { The labour movement's folk high } \\
\text { school in Gothenburg }\end{array}$ & $\begin{array}{l}\text { Göteborg (Västra } \\
\text { Götaland) }\end{array}$ & 1991 & Labour movement & 6 \\
\hline Ädelfors folk high school & Vetlanda (Jönköping) & 1957 & Labour movement & 5 \\
\hline Malmfältens folk high school & Kiruna (Norrbotten) & 1954 & (Partially) Labour movement* & 5 \\
\hline
\end{tabular}

*Malmfältens folk high school has shared ownership between labour movement organisations (LO och ABF), municipalities (Kiruna, Gällivare, Pajala), and the Norden Association.

The most common folk high schools are movement folk high schools, i.e. schools owned by popular civil society movements/organisations. The movement-owned schools certainly represent the majority of the folk high schools in Sweden (107 schools in 2014), but a significant number are owned by the county councils (43). The county-run folk high schools that were among the top ten schools in the 1967 folk high school group in parliament (Fornby, Gamleby and Grimslöv) are no longer at the forefront. The fact that movement folk high schools are more dominant in our study than in the 1967 study does not seem surprising, due to the contemporary dominance of short courses among the parliamentarians. The short courses in this context often have a clear party-related ideological orientation, which naturally suits a movement-owned folk high school better than a county-owned folk high school. Consistently, we can see that less politically oriented movement schools, whose owners are non-political civil society associations of various kinds (such as Hvilan, Fridhem and Önnestad folk high schools that were among the most common in Helldén's study), do not seem to be educational pathways for parliamentary politicians anymore. In the top 10 list (Table 3), we mainly find labour movement folk high schools, for example, schools owned by the blue-collar trade union confederation (LO) or the Workers' Educational Association (ABF). Besides labour folk high schools, we also find the temperance movement's folk high school Tollare and the environmental, peace and solidarity movements' Färnebo folk high school.

Regarding the relationship between the aforementioned differences between the proportion of folk high school participants in the various constituencies, and the most common folk high schools' geographic location, there is no clear cut pattern - rather, we find regional variations. It is obvious that the folk high schools in Stockholm (Runö and Tollare) are not particularly frequented by the MPs who were elected from the constituency of Stockholm. The Stockholm folk high schools do not seem to have any major importance as education centres for MPs elected in geographical proximity. These are rather folk high schools where MPs from other parts of the country have participated. When it comes to folk high schools in Västerbotten and Norrbotten in the north of Sweden, it is the opposite; they clearly serve as meeting and education venues for parliamentarians in geographical proximity. Medlefors folk high school in Skellefteå stands out as an almost inevitable pathway for the Social Democratic MPs from Västerbotten constituency. All five of the Social Democrats elected from 
Västerbotten in 2010 and 2014 participated in courses run by the school. Additionally, six of seven Social Democrats elected from the constituency of Norrbotten took at least one course at Medlefors. In Norrbotten, we can also note that all Social Democratic MPs were course participants at Sunderby folk high school in Luleå (but there was only one MP from Västerbotten).

The folk high schools of Viskadalen and Brunnsvik, both of which were among the most common schools in the 1967 study (Helldén, 1968), have largely retained their positions as relatively central education centres, though Brunnsvik no longer occupies the same prominent position. One of these traditional folk high schools is also characterised by its strong regional recruitment: out of the 18 MPs who passed Viskadalen in western Sweden, 15 came from the city of Gothenburg and three from other constituencies. In the case of Brunnsvik, which until recently was located in the small municipality of Ludvika (now in Borlänge), participation is more widespread, with two MPs from the constituency of Dalarna and two from Gävleborg, and single individuals elected from nine different constituencies from Västerbotten in the north to Skåne in the south of Sweden.

\section{Party schools and cross-party schools}

There are differences between the most common folk high schools when it comes to the political affiliation of MPs who have attended courses at the schools. To a large extent, the variation is linked to the owner/principals of the school, but there are also internal differences between labour movement-owned folk high schools. Table 4 shows the distribution of party affiliation among MPs from three of the most popular folk high schools: Medlefors, Viskadalen and Färnebo. Medlefors and Viskadalen rank as numbers one and two in the previous table (Table 3) and both are linked to the labour movement. We also present the distribution at Färnebo folk high school which is close to the other top schools in numbers, but linked to the peace, environmental and solidarity movements.

Table 4. Party affiliation among folk high school participants in the 2010 and 2014 Riksdag.

\begin{tabular}{lccc}
\hline Parliamentary party & $\begin{array}{c}\text { Medlefors folk high school } \\
\%(N)\end{array}$ & $\begin{array}{c}\text { Labour movement folk high school in Viskadalen } \\
\%(N)\end{array}$ & $\begin{array}{c}\text { Färnebo folk high school } \\
\%(N)\end{array}$ \\
\hline Centre Party & - & - & $7.7(1)$ \\
Christian Democrats & $8.7(2)$ & - & - \\
Green Party & $13.0(3)$ & - & $46.2(6)$ \\
Left Party & $13.0(3)$ & - & $30.8(4)$ \\
Liberal Party & - & - & $7.7(1)$ \\
Moderate Party & - & $100.0(18)$ & - \\
Social Democrats & $65.2(15)$ & - & $7.7(1)$ \\
Sweden Democrats & - & $100.0(18)$ & - \\
All & $100.0(23)$ & & $100.0(13)$ \\
\hline
\end{tabular}

Table 4 shows that Viskadalen is completely dominated by MPs from the Social Democrats, while Medlefors and Färnebo are schools where politicians from five parliamentary parties have attended.

Hence, we can conclude that there are clear differences in political recruitment between folk high schools even among those affiliated with the same political movement. More research, using empirical material other than registry data, is needed to explain the sharp difference between labour movement folk high schools such as Viskadalen and Medlefors. However, a brief comparison of how the two folk high schools presents themselves on their websites indicates a relationship between the different political recruitment patterns and the schools' intended target groups. Medlefors (2016) presents itself as a folk high school where "everyone who shares the 
belief in equality and human rights is welcome", thus including a rather wide political spectrum. This is also the case according to the folk high school registry, as confirmed by the types of courses that MPs from parties outside the labour movement have participated in at the school. They are clearly party-affiliated short courses, with names like "The Christian Democratic Policy for the Future" and "Green Election Kick-Off". Medlefors thus appears to be a somewhat cross-political school in the sense that parties with different ideological orientations locate their (seemingly internal training) courses at the school. In contrast, Viskadalen (2016) presents itself as "the leading education centre for the labour movement in western Sweden", where the educational activities are carried out "with our member organisations". Thus, the target group of the folk high school is defined in a narrower sense, and the strictly social democratic memberships of the schools' MPs are not so surprising.

At Färnebo folk high school there is also a mix of party memberships among the MPs who have participated in their courses, but the pattern differs from Medlefors. Here, MPs from different parties participate in the same courses. Based on the folk high school register it is clear, for example, that MPs (elected in 2010 and/or 2014) from five different parties (the Left Party, the Social Democrats, the Green Party, the Centre Party and the Liberals) participated in a course entitled "Transition for Climate Justice". This course, which has more of a thematic focus than a party political one, appears to be an expression of how the folk high school involves various politicians in courses related to the ideological profile of the school.

Thus, some folk high schools that stand out as key educational passages for Swedish MPs keep their selective party student base, while other movement-affiliated schools have a broader mix of party memberships among their students. This demonstrates that the schools' potential function in terms of socialisation of political elites is twofold: they can both operate as a forum for intra-party schooling and offer a shared space for (aspiring) MPs from different parities.

\section{An educational pathway to - or a venue for - the political elite?}

The study presented in this article is part of a broader research project focusing on educational pathways among the Swedish political elite. However, the analysis of data from the folk high school register makes it clear that the folk high schools are not just educational institutions that MPs pass through on the way to their political positions. It is also striking that MPs, to a large extent, are attending folk high school courses during their time in parliament; $13 \%$ of the Swedish MPs who were elected in 2010 attended a folk high school course while they were in office (from the autumn of 2010 until the spring of 2014). Table 5 shows that there are great differences between the political parties, but that MPs from all parties can be found among those who attended a folk high school course during their time as an elected MP.

Table 5. Folk high school course participation during time in office among MPs elected to the 2010 Swedish Riksdag.

\begin{tabular}{lcc}
\hline Parliamentary party & Numbers of MPs in the Riksdag & $\begin{array}{c}\text { Participated in folk high school during time as elected MP } \\
\%(N)\end{array}$ \\
\hline Centre Party & $N$ & $8.7(2)$ \\
Christian Democrats & 23 & $15.8(3)$ \\
Green Party & 19 & $32.0(8)$ \\
Left Party & 25 & $15.8(3)$ \\
Liberal Party & 19 & $4.2(1)$ \\
Moderate Party & 24 & $0.9(1)$ \\
Social Democrats & 107 & $24.1(27)$ \\
Swedish Democrats & 112 & $5.0(1)$ \\
All & 20 & $13.2(46)$ \\
\hline
\end{tabular}


What courses do the MPs take while in office? Exclusively, it is short courses. These short and flexible folk high school courses may include activities that could more generally be described as seminars or conferences. The MPs' role in the courses is not clear from our data. Neither can we determine to what extent the MPs interact with other students or staff at the school. In any case, it is obvious that the folk high schools arrange activities for people who could be seen as belonging to the Swedish political elite. For the political parties, the folk high schools, which may also take the role of conference centres, seem to be used as venues for internal partyrelated work. The link between the folk high school and the parliament is not only a matter of alumni relationships in terms of former students who have become MPs; there is also a more ongoing relationship in terms of recurring visits during the MPs' time in power.

\section{The new folk high school group in parliament: a summary}

In summary, there is still a folk high school group in the Swedish parliament. The MPs' folk high school participation consists mainly of short courses. There are obvious differences between parties in terms of level of participation, and over time the folk high schools have increasingly come to be used by members of the parties on the left of the political spectrum. The folk high school is to a significant extent used as a meeting place during an MP's political career, and not only as an educational pathway to power, as was emphasised in previous research.

Even though the folk high school still has its strongest ties to the parliamentary party that has the lowest proportion of MPs with higher education - the Social Democrats - we can conclude that the schools also seem to play a central role in the party that has the smallest proportion of low-educated individuals among its MPsthe Green Party (cf Nordvall \& Malmström, 2015). Folk high school participation transcends class, which is perhaps not so surprising given the common occurrence of both union courses, linked to the blue-collar trade unions, and courses focused on environmental and solidarity issues, which are areas that tend to attract the educated middle class (see for instance Vogel et al., 2003, p. 119).

The folk high schools have in previous research been seen as an alternative educational pathway (to formal education) into the Swedish political elite (Berggren, 1988; Erickson, 1966; Helldén, 1968). The presence of people in parliament with links to the folk high schools has also been discussed as a possible explanation for the strong political support for popular education in the parliament, assuming that these MPs through their own experience and contacts gained a positive image of, for example, the folk high school (Bogärde, 1974). Some folk high schools' function as elite educational institutions, fostering political leaders and providing organisational capital, is a third aspect discussed in the literature (Broady, 1990; Pauli, 2012). Our study shows that the new folk high school group is possibly most relevant to analyse in relation to the two latter aspects. It is apparent that, at least within the red-green party groups in parliament, but also in the Centre Party, several MPs have experience of the folk high school. What is new in our survey is that the relationship between the parliament and the folk high school not only appears to be associated with the presence of the folk high school alumni in parliament. In addition, it seems there is a continued contact between sitting members and the folk high school activities, in the form of participation in courses during their time as elected MPs.

The formative influence of the folk high school on politicians, which Helldén (1968) described as related to a long-term stay in a particular cultural environment where the MPs had expanded their cultural and social horizons, has likely changed considerably now that participation in longer courses is less common. What our study shows is that the folk high school especially stands out as a meeting place and a pathway for many MPs in 
the context of short courses.

Although short courses might not have the same formative influence as long courses, the MPs thereby come into contact with the folk high schools, their staff and educational environment, which make it reasonable to assume that some kind of relationship arises, if somewhat more brief than in the past, between the schools and the political elite that participate. Hence, the folk high school's proximity to political power has not disappeared, although its formative influence on individuals through long residential courses may have decreased.

We can also see that the folk high schools regionally can have a central position in relation to the political elite that MPs can be said to constitute. The labour movement folk high schools Medlefors and Viskadalen are clear examples of this, where the former appears to be an almost obligatory passage for Social Democratic MPs in the north of Sweden.

\section{Discussion}

Although there is previous research on MPs participating in folk high school courses, comparisons over time must be made with caution. Previous studies (Helldén, 1968; Andersson \& Lönnström, 1982) are based on research designs different from our study. There is, for instance, no data in previous studies concerning participation in short courses, even though we know from the general statistics on folk high schools that these courses were even more common during the 1970s than during the 2010s (Folkhögskolekommittén, 1990, p. 119; Folkbildningsrådet, 2015, p. 15). Presumably, the previous extensive short course activities also involved politicians. As for the longer courses, we lack data on participation before 1998 and thus are not covering the whole life span of the current MPs, while previous studies have more comprehensive data in relation to MPs' total participation in folk high school courses. The fact that the proportion of MPs who participated in longer courses is lower in our material than in previous studies should be understood partly in the light of our different research methods and material. However, this cannot reasonably explain the difference completely. Our study should therefore be seen as an indication that participation in these longer courses actually has decreased among members of parliament, which is in line with the trend Sundqvist (1990) found in his survey of Swedish MPs, 1989/1990.

However, it is difficult to say whether the patterns we found - for example, regarding participation in short courses - really should be regarded as something qualitatively new and a result of an actual change in the role of folk high schools, or whether this role was simply overlooked in previous research.

What we can say in terms of change over time is that the parties' relative proximity to the folk high school has altered. In the study from 1967, the Left Party (formerly the Communist Left Party) had no MPs with a folk high school background. Today, the Left Party has the largest proportion of folk high school participants among its MPs when it comes to both longer and shorter courses. One explanation for the previously low proportion of folk high school participants in the party is the historical struggle between Communists and Social Democrats in the labour movement, where groups opposed to a reformist position were actively marginalised by the dominant Social Democrats, both in trade unions and in popular education activities (Jansson, 2012). Recent studies suggest that this conflictual relationship in the labour movement today is largely obsolete, at least when it comes to popular education (Nordvall, 2013a). A partial explanation for the significant increase in folk high school participants in the Left Party could thus be the increased opportunity for participation in traditional labour movement folk high schools. The new position of the Left Party, as a folk high school-rooted party, should 
also be understood in light of the relatively new folk high schools Bona (funded in 1984) and Kvarnby (1991), of which the party at times has been the owner. Several leftist MPs also participated in courses at Färnebo folk high (1991).

Furthermore, we see a change regarding the position of the Centre Party who, together with the Social Democrats, used to have the strongest link to the folk high school compared to other parties. Today, the party seems to have lost this position in relation to other parties in the parliament.

In this sense, the two classical movement-based parties, the Social Democratic Party and the Centre Party, emanating from the labour movement and the farmers' movement, respectively, have evolved in different directions with regards to the folk high school institution since the studies of Héllden (1968) and Andersson and Lönnström (1982). Both parties have, however, experienced a transformation from broad-based mass parties to much slimmer organisations, which have lost more than $80 \%$ of their members since the 1970 s, and are considered similar in terms of party organisation and party culture (Barrling Hermansson 2004; Gidlund \& Möller 1999). Their development in two different directions should reasonably be understood in relation to the parties' different organisational links to the folk high schools, as well as in relation to socio-demographic changes in society affecting the parties differently.

Historically, the Social Democratic Party and the labour movement sent people for training to their own folk high schools to participate in courses designed for the movements' needs (Pauli 2012). The Centre Party and farmers' movement rather seem to have recruited people in rural areas who had attended folk high schools, mostly county owned, to acquire post-secondary or other educations for personal qualifications (cf Helldén, 1968). The former high level of folk high school participation in the Centre Party reflected the historical close bond between the farmer class and the folk high school. Hence, the combination of the diminishing number of farmers in Swedish society throughout the 1900 s and the simultaneous expansion of the education sector, providing postsecondary education for everyone, consequently have affected the folk high school participant rate in the Centre Party much more than in the Social Democratic Party. Although the number of blue-collar workers organised within the unions of social democratic-oriented Swedish Trade Union Confederation (LO) has decreased during recent decades, they still represent a substantial part of the labour force. ${ }^{5}$

The relative decline of MPs with a folk high school background within the Centre Party corresponds well with the general decline of MPs with a background as participants at county-owned folk high schools. Although the Centre Party, and the wider movement of closely related organisations ${ }^{6}$, are owners of a few folk high schools ${ }^{7}$, those schools do not seem to have the same role as political venues as the labour movement folk high schools. The schools became incorporated in the labour movement's organisation and were made part of its infrastructure, as opposed to the case of the Centre Party and the farmers' movement where they did not play a significant role.

There appears to be a correlation between the level of a party's "movement character" and its relationship to

\footnotetext{
${ }^{5}$ In 2016, the trade unions affiliated with LO organised 1,467,000 members, while The Federation of Swedish Farmers (LRF) organised 150,000 members (LO, 2016; LRF, 2016).

${ }^{6}$ For example, The Federation of Swedish Farmers (LRF) and Centre Party-related study association Studieförbundet Vuxenskolan (SV).

${ }^{7}$ Alma folk high school, Fridhem folk high school and Sommarbygden folk high school.
} 
various forms of popular education, such as folk high school education. This should also be considered when analysing the folk high school participant rate of the relatively new Green Party, which entered the Riksdag in 1988. It has established itself as a party with a clear link to folk high schools through its MPs' high participation rate in short courses. This may be understood in relation to previous research, indicating also that activists in newer social movements tend to participate in the traditional popular education activities such as folk high school courses and study circles (Nordvall, 2013b). Several MPs from the Green Party have participated in short courses at the ideologically closely related Färnebo folk high school, which is the folk high school with closest links to new social movements.

The various folk high schools seem to assume different positions in relation to the political elite and political parties. What is striking is that there are essentially only about ten folk high schools that, through their participants, seem to have a strong link to the Riksdag. Among these mainly labour movement-owned folk high schools, the differences are great when it comes to their importance from a regional and party political point of view, even if a consistent trend is that it is predominantly MPs from the red-green parties that seem to participate in their courses. Possibly, this pattern indicates that despite its continued closeness to political power, the broad cross-party legitimacy of folk high schools in the Swedish parliament may be changing. The relatively low proportion of folk high school participants among the bourgeois parties could be seen as a crack in this broad legitimacy. According to Bogärde's reasoning (1974), this eventually, in the long run, may affect the wide political support for folk high schools and popular education in parliament. However, parallel to the long period of decline in the number of MPs with a folk high school background, state support for popular education has remained stable (Fejes \& Nordvall, 2015; Bjursell \& Nordvall, 2016). Thus, it is more likely that the reasons behind the wide political support for state subsidies to folk high schools and popular education in Sweden are mainly related to something else than to MPs' personal experiences of folk high schools. The widespread support among leading politicians in Sweden, and the belief in the democratic role of popular education (cf. Sandahl, 2016), apparently persist despite the fact that the folk high school no longer seems to hold the same position as a pathway to political positions for a wide range of political parties. The only explicit political opposition to government support to the popular education sector in Sweden comes from the far-right nationalist Sweden Democrats. Although that party does have few folk high school attendees among its MPs, their ambition to decrease state funding is rather politically motivated, as the party expresses criticism of the multiculturalism they find too widespread among popular education organisations (Myrbäck 2017).

The folk high schools' function as providers of organisational capital, a social and symbolic asset that could benefit a person's political career, may still be relevant on the green and left side of the political spectrum. The fact that there are a few "elite" folk high schools, operating as venues where parliamentarians pass by during various points in their career, make them still relevant to consider as providers of organisation capital, as described by Broady (1990). However, rather than being a Nordic version of the Oxbridge phenomenon, the impact of these folk high schools should be seen as only one aspect of many to consider when analysing the relationship between the educational system and the reproduction of political elites in Sweden. 


\section{References}

Andersson, B. \& Lönnström, P. (1982). Politikern och folkbildningen: En enkätundersökning, 1977-1978 av riksdagsledamöternas folkbildningsanknytning och attityder till studieförbundens arbete. In Andersson, Bo (Ed.) Centralt och lokalt - förr och nu (pp. 87-106). Södertälje: Studieförbundet Vuxenskolan.

Andersson, M. \& Mellander, C. (2011). Folkbildning i Sveriges kommuner-spridning och relation till socioekonomiska strukturer. Stockholm: Folkbildningsrådet.

Arvidson, L. (1985). Folkbildning i rörelse: pedagogisk syn i folkbildning inom svensk arbetar-rörelse och frikyrkorörelse under, 1900- talet - en jämförelse. Malmö: Liber.

Barrling Hermansson, K. (2004). Partikulturer. Uppsala: Uppsala universitet.

Berggren, H. (1988). Proletärerna vid Mimers brunn: bildning och politisk mobilitet inom arbetarrörelsen, 19061920. Historisk tidskrift, 1988(2), 178-198.

Berndtsson, R. (2003). Nya folkhögskolor. Stockholm: Folkbildningsrådet

Best, H., \& Cotta, M. (2000). Parliamentary representatives in Europe 1848-2000. Oxford University Press.

Bjursell, C. \& Nordvall, H. (2016) Inledning. In Folkbildningens frihet och värde: metaperspektiv på folkhögskolor och studieförbund (pp. 8-22). Stockholm: Folkbildningsrådet.

Bogärde, B. (1974). Svenska folkhögskolans lärarförening och staten, 1902-1970: en studie i organisationsinflytande. Uppsala: Rabén \& Sjögren.

Bourdieu, P. (1996). The state nobility. Cambridge: Polity Press.

Broady, D. (1990). Sociologi och epistemology. Diss. Stockholm : Högsk. för lärarutbildning

Canfield, A. T. (1965). Folk High Schools in Denmark and Sweden: A Comparative Analysis. Comparative Education Review 9 (1), 18-24.

Erickson, H. (1966). Adult education and Swedish political leadership. International Review of Education 12 (2), 129-143.

Fejes, A \& Nordvall, H. (2014). Folkbildning och vuxenutbildning i skolkrisorkanens öga. KOM: kommunikation mellan kommunala vuxenutbildare 42(3), 4-8.

Folkbildningsrådet (2015). Fakta om folkbildning. Stockholm: Folkbildningsrådet.

Folkhögskolekommittén (1990). Folkhögskolan iframtidsperspektiv: betänkande från Folkhögskolekommittén. Stockholm: Allmänna förl..

Gaxie, D. \& Godmer, L. (2007). Cultural Capital and Political Selection. In Cotta, M. \& Best, H. (ed.) Democratic representation in Europe: diversity, change, and convergence (pp. 106-135). Oxford: Oxford University Press.

Gidlund, G. \& Möller, T. (1999). Demokratins trotjänare: lokalt partiarbete förr och nu. Stockholm: Fakta info direkt.

Göransson, A. (2007). Maktens kön: kvinnor och män i den svenska makteliten på 2000-talet. Nora: Nya Doxa Hartmann, M. (2010). Elites and Power Structures. In Immerfall, S. \& Therborn, G. (red.) (2010). Handbook of European societies: social transformations in the 21st century (pp. 291-324). New York: Springer.

Helldén, A. (1968). Folkhögskolegruppen i riksdagen. In Degerman, D. (ed.) Svenskfolkhögskola 100 år. D. 4 (pp. 59-225). Stockholm: Liber.

Holmberg, S. \& Esaiasson, P. (1988). De folkvalda: en bok om riksdagsledamöterna och den representativa demokratin i Sverige. Stockholm: Bonnier.

Jansson, J. (2012). Manufacturing consensus: the making of the Swedish reformist working class. Diss. Uppsala : Uppsala universitet.

Johansson, L. \& Bergstedt, B. (2015). Visions unite through the concept of democracy: The school and the Popular Adult Education, Scandinavian. Journal of Educational Research, 59(1), 42-57. 
Kurtz, D. \& Simon, M. (2007). The education of the American political elite. The Social Science Journal 44, 480494.

Larsson, S. (2013). Folk high schools as educational avant-gardes in Sweden. In Laginder, A-M, Nordvall, H. \& Crowther, J. (Eds.) Popular education, power and democracy: Swedish experiences and contributions (pp. 72-97). Leicester: NIACE.

Lie Andersen, P. (2014). Den norske politiske eliten: Sammenhangen mellom politike posisjoner, klassebakgrunn og utdanning. In Korsnes, O., Nordli Hansen, M. \& Hjellbrekke (Eds.) Elite og klasse i et egalitært samfunn (pp. 144-166). Oslo: Universitetsforlaget.

Lilleker, Darren G. (2003). Interviewing the political elite: Navigating a potential minefield. Politics 23(3), 207-214. LRF (2016) Statistik LRFs medlemmar och förtroendevalda 2016. Retrieved November 15, 2016, https://Irf.se/globalassets/dokument/mitt-Irf/fortroendevald-i-Irf/valberedning/statistik-sa-sermedlemmarna-ut.pdf

LO (2016) Medlemsantal åren 1899-2015. Retrieved November 15, 2016, from http://www.lo.se/start/lo_fakta/medlemsantal_aren_1899_2015

Maliszewski, T. (2008). Den svenska folkhögskolan. Linköping: Vuxenutbildarcentrum.

Myrbäck, S. (2017). SD vill kontrollera kurser på folkhögskola. Tidningen Folkhögskolan. Dated March 03, 2017. Retrieved May 09, 2016, from http://tidningenfolkhogskolan.se/sd-vill-stoppa-kurser-pa-folkhogskola/

Nordvall, H. (2013a). ABF och det partipolitiska folkbildningsarbetets samtida funktioner. In Bjurström, E. \& Harding, T. (Eds.) Bildning och demokrati. Nya vägar i det svenska folkbildningslandskapet (pp. 223-256) Stockholm: Carlssons.

Nordvall, H. (2013b). The global justice movement encounters Swedish popular education. In Laginder, A-M, Nordvall, H. \& Crowther, J. (eds.) Popular education, power and democracy: Swedish experiences and contributions (pp 122-146). Leicester: NIACE.

Nordvall, H. \& Malmström, L. (2015). Den folkligt bildade politikern: Akademiska kunskaper och det symboliska kapitalets logik inom den socialdemokratiska riksdagsgruppen i Sverige. Nordisk kulturpolitisk tidskrift, $18(2), 233-249$.

Norris, P., \& Lovenduski, J. (1995). Political recruitment. Cambridge: Cambridge University Press.

Pauli, P. (2012). Rörelsens ledare: karriärvägar och ledarideal i den svenska arbetarrörelsen under 1900-talet. Diss. Göteborg: Göteborgs universitet.

Rubenson, K. (2013). Towards lifelong learning for all in Europe: Understanding the fundamental role popular education could play in the European Commission's strategy. In Laginder, A-M, Nordvall, H. \& Crowther, J. (Eds.) Popular Education, Power and Democracy: Swedish Contributions and experiences (pp. 14-31) Leicester: NIACE.

Runesdotter, C.(2010). I otakt med tiden?: folkhögskolorna i ett föränderligt fält. Göteborg: Göteborgs universitet. SOU, 1990:44. (1990). Demokrati och makt i Sverige: Maktutredningens huvudrapport. Stockholm: Allmänna förlaget.

Statistics Sweden, SCB (2016). Nominerade, valda och ej valda kandidater i riksdagsval efter kön, parti och utbildningsnivå. Antal och andelar. Valår, 1991 - 2014. Retrieved March 02, 2016, from http://www.statistikdatabasen.scb.se/pxweb/sv/ssd/START ME ME0107 ME0107C/ME0107T25/? rxid=b55d8959-08df-418d-9039-56be8a9edb24.

Sundqvist, A. (1990). Politikers syn på folkbildningsarbete i studieförbund och folkhögskolor. (Unpublished report) Linköping: Institutionen för pedagogik och psykologi, Linköpings universitet.

Turunen, A. (2015). Att snickra medborgarskap? Nordisk kulturpolitisk tidskrift, 18(2), 219-232.

Vogel, J., Amnå, E., Munck, I., \& Häll, L. (2003). Föreningslivet i Sverige: välfärd, socialt kapital, demokratiskola. 
Stockholm: Statistiska centralbyrån (SCB).

Ye, R., \& Nylander, E. (2015). The transnational track: state sponsorship and Singapore's Oxbridge elite. British Journal of Sociology of Education, 36(1), 11-33. 